\title{
Peran Guru PAI dalam Membentuk Kesadaran Hukum Berlalu Lintas Siswa Kelas XII di SMK Texmaco Purwasari
}

\author{
Alif Kurniawan \\ STAI DR.KH.EZ.Muttaqien Purwakarta, Indonesia \\ alif96kurniawan@gmail.com \\ Surya Hadi Darma \\ STAI DR.KH.EZ.Muttaqien Purwakarta, Indonesia \\ adhie.dharma@gmail.com
}

Abdurrahman Saleh

STAI DR. KH. EZ. Muttaqien Purwakarta abahyasmin81@gmail.com

DOI: https://DOI.org/10.52593/pdg.02.2.05

Naskah diterima: 07 Juni 2021, direvisi: 27 Juli 2021 disetujui : 28 Juli 2021

\begin{abstract}
This research is based on the results of observations made by the author, namely the number of victims of traffic accidents aged 16-30 years, many victims of traffic accidents, traffic accidents in Karawang every year lose up to 500 children's lives under the age of 25 years, and including six students from class XII SMK Texmaco Purwasari among them. The author assumes that the incident was caused by the low awareness of students in understanding traffic laws. This study aimed to find out the answers to assumptions regarding students' awareness in understanding traffic laws and the role of teachers in shaping traffic awareness, especially at SMK TEXMACO Purwasari. The approach used by the researcher is a descriptive qualitative approach with theoretical analysis of -O-R (Stimulus Organism Response) to identify that student awareness can be formed through the communication of the role of the PAI teacher. This study indicates that the role of the PAI teacher in shaping student traffic law awareness includes: a) the first as an Informator, b) the dual role as an organizer, $c$ ) the third role as a motivator. d) The fourth role is as a facilitator, e) the fifth role is as a supervisor, f) the last role is as a class manager.
\end{abstract}

Keywords: Legal awareness, Learning Communication, Teacher's Role 


\begin{abstract}
Abstraksi
Penelitian ini dilatar belakangi dari hasil observasi yang penulis lakukan yaitu banyaknya korban kecelakaan lalu lintas usia 16-30 tahun banyak menjadi korban kecelakaan lalu lintas, kecelakaan lalu lintas di Karawang setiap tahunnya kehilangan hingga 500 nyawa anak di bawah usia 25 tahun, dan termasuk 6 siswa dari kelas XII SMK Texmaco Purwasari diantaraya. Asumsi penulis bahwa kejadian itu disebabkan oleh rendahnya kesadaran siswa dalam memahami hukum berlalu lintas. Tujuan penelitian ini adalah untuk mengetahui jawaban asumsi berkenaan dengan kesadaran siswa dalam memahami hukum berlalu lintas, serta peran guru dalam membentuk kesadaran berlalu lintas khususnya di SMK Texmaco Purwasari. Pendekatan yang digunakan oleh peneliti adalah pendekatan kualitatif deskriptif dengan analisa teori -O-R (Stimulus Organisme Respon) untuk menemukenali bahwa kesadaran siswa dapat dibentuk melaui komunikasi peran guru PAI. Hasil Penelitian ini menunjukan bahwa peran Guru PAI dalam Membentuk Kesadaran Hukum berlalu lintas siswa antara lain : a) pertama sebagai Informator, b) Peranan yang kedua yaitu sebagai organisator, c) Peranan yang ketiga yaitu sebagai motivator. d) Peranan yang Keempat yaitu sebagai fasilitator, e) Peranan yang kelima yaitu sebagai pembimbing, f) Peranan yang terakhir yaitu sebagai pengelola kelas.
\end{abstract}

Kata Kunci : Peran Guru, Kesadaran Hukum, Komuniaksi, Pembelajaran

\title{
A. Pendahuluan
}

Saat ini sepeda motor telah menjadi sarana transportasi andalan berbagai kalangan karena dinilai lebih ekonomis dan anti macet. Karena efektifnya sarana trasportasi tersebut, disamping ada tukang ojek konvensional, di kota-kota besar seperti Jakarta dan Bandung saat ini marak usaha ojek berbasis aplikasi atau disebut juga ojek online sebagai cara efektif menembus kemacetan kota yang parah. ${ }^{2}$ Selain itu, Pengendara dibawah umur merupakan fenomena yang semakin menjamur dan juga dianggap wajar, terutama di kota-kota besar dan maupun didesa, semakin lazimnya fenomena ini, kini tidak hanya pelajar SMA, bahkan anak SMP dan SD (Yuliana, 2019).

Berkendara dengan sepeda motor khususnya dikalangan pelajar yang usianya di bawah 17 tahun saat ini sudah menjadi hal yang sangat lumrah, entah apa alasan yang mendasar dengan sangat mudah sekali orang tua biologisnya mengizin kan dan membolehkannya berkendara ke sekolah. 
Padalah menurut pasal 81 (2) Undang-undang Republik Indonesia No. 22 tahun 2009 tentang lalu lintas dan angkutan jalan yang berbunyi, untuk mendapatkan SIM A, C dan D, mereka harus berusia paling rendah 17 tahun.

Hai orang-orang yang beriman, taatilah Allah dan taatilah Rasul (Nya), dan ulil amri di antara kamu. Kemudian jika kamu berlainan pendapat tentang sesuatu, maka kembalikanlah ia kepada Allah (Al Quran) dan Rasul (sunnahnya), jika kamu benar-benar beriman kepada Allah dan hari kemudian. Yang demikian itu lebih utama (bagimu) dan lebih baik akibatnya. (QS. An- Nisa ayat 59).

Dalam Al-Qur'an surat An- Nisa' ayat 59 yang berisi tentang perintah kepada seluruh manusia untuk menaati ulul amri (Pemimpin) setempat, terutama dalam menaati peraturan berlalu lintas, bagaimana etika dan tatacara berlalu lintas, dan mematuhi hukum-hukum yang tertera di dalam lalu lintas.

Dengan melihat kondisi sekarang kesadaran hukum berlalu lintas di Indonesia khususnya dikalangan pelajar dirasa masih rendah, kesadaran hukum berlalu lintas pengendara yang rendah dapat menimbulkan tingginya kemungkinan tingkat pelanggaran lalu lintas yang terjadi. Banyak sekali yang dapat dijumpai permasalahan yang berkaitan dengan masalah pelanggaran lalu lintas yang dilakukan pengendara, seperti pelanggaran tidak menghidupkan lampu pada siang hari, tidak memiliki SIM atau STNK, berboncengan lebih dari dua orang, tidak memakai helm, menerobos lampu merah, dan tidak lengkapnya kendaraan bermotor (tidak adanya nomor kendaraan, kaca spion tidak lengkap, knalpot tidak sesuai standar nasional, dan memperkecil ukuran ban). Kesedaran hukum berlalu lintas pengendara yang kurang, tidak jarang juga sering menimbulkan kecelakaan lalu lintas yang membawa dampak bagi pengendara lain atau sesama pengguna jalan.

Menurut informasi dari SATLANTAS Karawang bapak Prasetya bahwa jumlah kendaraan bermotor di kabupaten Karawang dari tahun ketahun mengalami peningkatan, pada tahun 2012 terdapat 540,720 sepeda motor, dan 23,723 mobil, tahun 2013 terdapat 585,228 sepeda motor, dan 30,703 mobil, tahun 2014 terdapat 639,689 sepeda motor, dan 39,383 mobil, pada tahun 2015 terdapat 677,362 sepeda motor, dan 47,685 mobil, dan pada tahun 2016 terdapat 750,552 sepeda motor, dan 57,369 mobil. Peningkatan kepemilikan kendaraan bermotor ternyata diikuti dengan 
meningkatnya jumlah kecelakaan lalu lintas di jalan raya. Berdasarkan data Badan pusat statistik Indonesia jumlah kecelakaan lalu lintas juga mengalami perkembangan, pada tahun 2017 terjadi 534 jumlah kecelakaan yang terdiri dari 290 korban meninggal dunia, 96 korban luka berat dan 425 korban luka ringan, tahun 2018 terjadi 630 jumlah kecelakaan yang terdiri dari 266 korban meninggal dunia, 88 korban luka berat, dan 678 korban luka ringan. Jika dilihat dari usia, korban kecelakaan lalu lintas usia 16-30 tahun banyak menjadi korban kecelakaan lalu lintas, kecelakaan lalu lintas di Karawang setiap tahunnya kehilangan hingga 500 nyawa anak di bawah usia 25 tahun, dan termasuk 6 siswa dari kelas XII SMK TEXMACO Purwasari diantaraya.

Melihat kondisi bahwa pelanggar lalu lintas saat ini banyak di lakukan oleh siswa atau peserta didik, nampaknya sekolah sebagai lembaga pendidikan formal mempunyai peran yang sangat penting dalam memberikan pemahaman berlalu lintas dan membentuk sikap dan perilaku yang taat akan aturan-aturan hukum terutama terhadap aturan lalu lintas. Guru PAI sebagai agen pendidikan yang berperan membentuk siswa yang berkarakter, bukan hanya memberikan pengetahuan, guru PAI juga mempunyai peran dalam membentuk sikap sosial dan spritual siswa. Pendidikan formal dan non formal mengambil peran dengan menanamkan kesadaran hukum kepada peserta didiknya tentang bagaimana masyarakat menjadi baik, tentang apa yang menjadi haknya serta kewajiban sebagai warga negara Indonesia dan bagaimana cara memperoleh perlindungan hukum.

Dengan para siswa diberikan pengetahuan tersebut dapat menjadi patokan atau pedoman bagi mereka dan kesadaran hukum itu akan muncul dengan sendirinya, karena kesadaran hukum tidak bisa dipaksakan. Sejak dini peserta didik dapat dibiasakan dengan setiap sekolah hendaknya ada peraturan tertulis, sehingga apabila ada siswa yang melanggar peraturan maka akan ditindak sesuai dengan perbuatan yang dilanggar sebagai bentuk menanamkan rasa bertanggung jawab dan meningkatkan kesadaran hukum siswa.

Dengan demikian, penulis ingin sekali mengkaji lebih jauh dengan sepengetahuan penulis, yang nantinya di kembangkan dengan merujuk referensi yang ada. Penelitian yang secara spesifik membahas tentang bagaimana peran guru PAI dalam membentuk karakter tersebut yang nantinya semoga bermanfaat khususnya bagi penulis dan umumnya bagi para pembaca. Berdasarkan paparan di atas penulis 128 | Paedagogie: P-ISSN: 2337-6848, E-ISSN : 2723-5971 
menganggap perlu mengkaji secara mendalam tentang: "Peran Guru Pai Dalam Membentuk Kesadaran Hukum Berlalu Lintas Siswa Kelas Xii Di Smk Texmaco Purwasari”. (Study Deskriptif di SMK Purwasari kab. Karawang).

Berdasarkan latar belakang di atas dapat di identifikasikan sebagai berikut yaitu Rendahnya kesadaran siswa untuk taat berlalu lintas. Tingginya angka kecelakaan dikalangan siswa kelas XII SMK Texmaco Purwasari, Kurangnya kepedulian guru dan orangtua. Adapun tujuan penelitian adalah: 1) Mengetahui pemahaman siswa tentang kesadaran hukum berlalu lintas; 2) Peranan guru PAI dalam membentuk kesadaran hukum berlalu lintas siswa kelas XII di SMK Texmaco Purwasari; 3) Mengetahui faktor pendukung dan penghambat guru PAI dalam membentuk kesadaran hukum berlalu lintas bagi siswa.

\section{B. Teori / Konsep}

\section{Peran Guru}

Dalam kehidupan nyata, membawakan peran berarti menduduki suatu posisi social dalam masyarakat. Peran dijalankan berdasarkan status sosial yang dipilih seorang individu. Contoh, seorang ibu merupakan status sosial. Peran yang dijalankan seorang ibu adalah membimbing, mendidik, dan membesarkan anak-anaknya (Harahap, 2018).

Secara etimologis, guru sering disebut pendidik. Dalam bahasa Arab, ada beberapa kata yang menunjukkan profesi ini, seperti mudarris, mu'allim, murabbi dan mu'addib, yang meski memiliki makna yang sama, namun masing- masing mempunyai karakteristik yang berbeda (Gunawan, 2011).

Mengutip perkataan K.H. Imam Zarakasyi seorang guru mestinya menjadi pendidik yang betul-betul ikhlas, penuh tanggung jawab dan mengembangkan diri lillahi ta'ala, lil-'ibadah. ${ }^{8}$ Guru itu tidak hanya berorientasi pada kecakapan yang berdimensi ranah cipta sajatetapi kecakapan yang berdimensi ranah rasa dan karsa.

Dalam Perspektif psikologi Pendidikan, (Manpan Drajat, 2015)mengajar pada prinsipnya berarti proses perbuatan seseorang (guru) yang membuat orang lain (siswa) belajar, dalam arti mengubah seluruh dimensi prilakunya. Prilaku ini meliputi tingkah 
laku yang bersifat terbuka seperti keterampilan membaca (ranah karsa), juga yang bersifat tertutup seperti berfikir (ranah cipta) dan berperasaan (ranah rasa).

\section{Pendidikan Agama Islam}

Terkadang apabila ingin membahas seputar Islam dalam Pendidikan merupakan suatu hal yang sangat menarik terutama dalam kaitannya dengan upaya pembangunan sumber daya manusia. H. Nasir A. Baki, mendefinisikan pendidikan sebagai usaha meningkatkan potensi diri dari segala aspek, baik menyangkut pendidikan formal, informal maupunpendidikan non formal.(Muhamad Ridwan Effendi, Rudi M. Barnansyah, 2019) Oleh karena itu, pendidikan dipahami sebagai suatu proses dalam rangka memanusiakan manusia melalui lingkungan pendidikan, atau dengan kata lain hubungan antara Islam dan pendidikan bagaikan dua sisi keping mata uang. Artinya, Islam dan pendidikan mempunyai hubungan filosofis yang sangat mendasar baik secara ontologis, epistimologis maupun aksiologis (Samrin, 2015).

Selanjutnya, adapun pengertian pendidikan agama menurut Zakiah Daradjat merupakan pembentukan kepribadian muslim atau perubahan sikap dan tingkah laku sesuai dengan petunjuk ajaran Islam. Menurut Muhammad Qutb, sebagaimana yang dikutip Abdullah Idi dan Toto Suharto, memaknai pendidikan agama sebagai usaha melakukan pendekatan yang menyeluruh terhadap wujud manusia, baik dari segi jasmani maupun ruhani, baik dari kehidupan fisik maupun mentalnya, dalam kegiatan di bumi ini (Samrin, 2015).

\section{Kesadaran Hukum}

Hukum merupakan perumusan pendapat atau pandangan tentang bagaimana seseorang bertingkah laku. Hukum adalah kehendak ciptaan manusia berupa norma-norma yang berisikan petunjuk-petunjuk tingkah laku, tentang apa yang boleh dilakukan, yang dilarang, dan yang dianjurkan untuk dilakukan (Asiah, 2009).

Kesadaran hukum pada hakekatnya adalah bicara tentang kesadaran atau nilai-nilai yang terdapat di dalam diri manusia tentang hukum yang ada atau tentang hukum yang diharapkan. ${ }^{13}$ Hukum adalah karya manusia berupa normanorma yang berisikan petunjuk-petunjuk tingkah laku. Hukum merupakan pencerminan dari kehendak manusia tentang bagaimana seharusnya masyarakat 130 | Paedagogie: P-ISSN: 2337-6848, E-ISSN : 2723-5971 
dibina dan kemana harus diarahkan. Oleh karena itu pertama-tama, hukum mengandung rekaman dari ide-ide yang dipilih oleh masyarakat tempat hukum itu diciptakan. Ide- ide tersebut berupa ide mengenai keadilan (Hasibuan, 2007).

\section{Kesadaran Hukum Berlalu Lintas}

Kesadaran hukum seseorang yang tinggi tidak selamanya dalam menanggapi sebuah hukum tertentu dan memiliki ketaatan hukum yang tinggi, dan juga sebaliknya seseorang yang memiliki kesadaran hukum yang rendah tidak akan selamanya melekat pada diri seseorang tersebut memiliki kesadaran hukum yang rendah. Meningkatkan kesadaran hukum masyarakat dalam berlalu lintas dapat mencegah dan mengurangi angka kecelakaan lalu lintas.

Banyak cara yang dapat dilakukan dalam meningkatkan kesadaran hukum melalui cara sebagai berikut: (Kuncorowati, 2009)

1. pendidikan, baik disekolah formal maupun sekolah non formal dari dini perlu ditanamkan kesadaran hokum;

2. Penyuluhan atau sosialisasi, penyuluhan hukum sebagai bentuk penyadaran, dan menstransformasikan nilai-nilai dan norma-norma yang memiliki tujuan menyadari, paham dan melaksanakan ketentuan- ketentuan kaidahkaidah hukum sebagai pedoman berperilaku dan bertindak dalam kehidupan masyarakat;

3. peranan aparat penegak hokum;

Laksamana dalam penelitiannya mengungkapkan mewujudkan kesadaran hukum masyarakat untuk berlalu lintas dapat dilakukan dengan cara sebagai berikut:

a) Menciptakan budaya taat hukum masyarakat untuk tertib berlalu lintas

b) Penegakan hukum lalu lintas sebagai upaya menciptakan kesadaran hukum masyarakat untuk terciptanya ketertiban (Rechtorder)

c) Peningkatan keselamatan lalu lintas (Laksamana, 2010). 
Kesadaran hukum seseorang dapat ditingkatkan, meningkatkan kesadaran hukum seseorang tidak perlu dengan cara-cara keras seperti mengancam dengan cara paksaan, kesadaran hukum itu tidak bisa dipaksakan dan tidak mungkin diciptakan dengan adanya paksaan, karena kesadaran itu berasal dari dalam diri sendiri. Seseorang tersebut dengan sadar mengakui adanya suatu aturan hukum tertentu, kesadaran akan hak dan kewajiban seseorang tersebut sebagai warga negara Indonesia yang baik.

Jadi dapat disimpulkan bahwa kesadaran hukum berlalu lintas seseorang sangat diperlukan sebagai bentuk seseorang sadar akan adanya aturan-aturan mengenai lalu lintas, kemudian dari pengetahuannya tersebut, seseorang menunjukan sikap dan perilaku sesuai dengan aturan lalu lintas sebagai bentuk kepatuhan hukum dalam berlalu lintas. Kepatuhan hukum berlalu lintas seseorang sebaiknya didasarkan pada sadarnya seseorang itu akannya suatu aturan berlalu lintas, dan juga berdasarkan bahwa secara sadar mengakui bahwa kepatuhan terhadap hukum berlalu lintas sebagai penunjang keselamatan berlalu lintas baik diri sendiri maupun orang lain.

\section{Metode Penelitian}

Pendekatan yang digunakan oleh peneliti adalah pendekatan Kualitatif Deskriptif yang dilaksanakan pada bulan Oktober tahun 2019, yang bertempat di SMK Texmaco Purwasari, Karawang. Data Primer, yang bersumber dari hasil penelitian dan wawancara mendalam kepada guru PAI dan peserta didik kelas XII SMK Texmaco Purwasari, Karawang.

\section{Hasil Pembahasan}

\section{Kesadaran Hukum Berlalu Lintas di SMK Texmaco}

Hasil Penelitian lapangan yang dilakukan peneliti menemukan bahwa sebagian besar siswa SMK Texmaco Purwasari menyatakan sangat menyadari akan hukum lalu lintas yang harus di taati, sesuai dengan paparan Ananda Taopik Paridi kelas XII TSM ketika ditanyakan tentang tata cara berlalu lintas dan rambu-rambu yang yang berlaku di lalu lintas dia memaparkan.

Tidak menerobos lampu rambu- rambu lalu lintas, bagi pejalan kaki berjalan di trotoar, jika mau mendahului kendaraan lain sebaiknya menyalip dari sebelah kanan, 132 | Paedagogie: P-ISSN: 2337-6848, E-ISSN : 2723-5971 
dan memberikan lampu sen ketika mau berbelok. Dilarang berhenti, jalan satu arah, dilarang memutar balik, dan dilarang parkir (Wawancara Taopik Paridi, n.d.).

Dari pernyataan tersebut tentu kita tau bahwa beberapa siswa sangat tau aturan lalu lintas yang berlaku, Reza Pratama kelas XII TPMI pun memeberikan penjelasanya ketika ditanyakan mengenai kelengkapan persyaratan menjadi pengguna lalu lintas dan aturan lainya dia menjelaskan jenis SIM yang harus dimiliki bagi setiap pengendara:

SIM C bagi pengendara motor, SIM A bagi pengendara mobil, dan STNK. dan kecepatan berkendara di jalan raya maksimal 100 kilometer per jam dan minimal 60 kilometer per jam.

Ini menjadi bukti bahwa siswa mengerti sebagian besar aturan lalu lintas, sebagian lainya juga menjelelaskan kelengkapan kendaraan yang harus di taati.

Ban sesuai dengan standar nasional Indonesia, knalpotnya yang tidak menggunakan rakitan/sesuai dengan standar knalpot, menggunakan kaca spion standar 2 buah, dan ada plat nomor sesuai dengan STNKnya (Wawancara Muhammad Soleh, n.d.).

Salah seorang siswa juga memberikan penjelasan sebagai berikut ketika ditanyakan pendapat tentang pelanggaran menggunakan telepon atau $\mathrm{Hp}$ ketika berkendara

Sangat tidak baik bagi pengguna/orang lain karena bisa terjadi kecelakaan, maka dari itu kalau menggunakan Handphone kita sebagai pengendara harus menepi/berhenti dipinggir jalan terdahulu (Wawancara Bunga Ayu Lestari, n.d.).

Dari pernyataan tersebut tentu responden sangat tau bagaimana aturan menggunakan handphone ketika berkendara, dijelaskan juga oleh siswa lainya sebagai berikut:

Lebih baik pengendara hanya fokus dengan mengendarai atau jika mau menggunakan Handphone berhenti terlebih dahulu di pinggir jika keadaanya penting untuk menggunakan Hand phone .(Wawancara Alin Noor Kholis, n.d.)

Banyak dari penjelasan yang dipaparkan oleh siswa yang kami wawancara mengenai cara berlalu lintas, kemudian tanggapan bagi pelanggaran lalu lintas, hampir 
seluruhnya mengetahui bagaimana cara berlalu lintas dan atau akibat pelanggaran lalu lintas. Dalam beberapa penjelasan mereka juga menanggapi terhadap kasus pelanggaran lalu lintas seperti yang di paparkan oleh

Yang tidak menggunakan helm dalam berkendara berarti dia sudah percaya diri dan siap menerima resiko jika terjadi kecelakaan (Wawancara Alin Noor Kholis, n.d.)

Bahkan dengan sangat yakin dan lantang salahsatu siswa mengatakan bahwa mereka yang menggunakan trotoar untuk menerobos kemacetan adalah orang yang tidak cerdas dan tidak tau aturan,

Trotoar itu pejalan kaki, kalau ada pengendara yang menggunakan trotoar itu dia salah berarti dia tidak tahu aturan (Wawancara Muhammad Soleh, n.d.)sols.

Pengendara motor sebaiknya mengetahui atau lebih cerdas lagi kalau sebenarnya trotoar itu tempat orang pejalan kaki bukan untuk kendaraan bermotor. Ada pelanggaran yang kerapkali menjadi langganan para pelanggar lalu lintas yaitu tidak menggunakan helm, dengan alasan jarak yang dekat dan merasa akan baik-baik saja jika tidak menggunakanya, yang padahal ketika tidak menggunakan helm tentu akan sangat berbahaya bagi keselamatan karena ketika terjadi kecelakaan lalu lintas kepala samasekali tidak mempunyai pelindung jika tidak menggunakan helm dan akan menyebabkan kematian, menurut hasil wawancara dengan salahseorang siswa juga mencoba menjelaskan bagaimana pentingnya menggunakan helm sangat tidak baik dan merugikan diri sendiri, bisa kena tilang dan juga kalau kecelakaan kepala tidak ada pelindung dan berbahaya.

Hal lain yang sering dilanggar dari aturan lalu lintas adalah menerobos lampu merah, seharusnya kita menyadari bahwa ketika adanya lampu lalu lintas pada sebuah persimpangan jalan, berari jalan tersebut sangat rawan akan kecelakaan, karena adanya banyak persimpangan yang menyebabkan kendaraaan saling menerobos sampai mengakibatkaan kemacetan Panjang jika tidak diatur oleh lampu lalu lintas, maka tentu ketika kita melangar aturan tersebut akan sangat membahayakan selain diri sendiri juga orang lain yang berada di persimpangan jalan. Salah seorang siswapun coba menjelaskan tentang pelanggaran lampu lalu lintas.

Semua itu akan mengakibatkan kecelakaan lebih baik pengendara lebih sabar dalam menunggu lampu lintas (Wawancara Alin Noor Kholis, n.d.).

134 | Paedagogie: P-ISSN: 2337-6848, E-ISSN : 2723-5971 
Dari beberapa siswa juga mencobamenjelaskan bagaimana pentingnya lampu lalu lintas.

Perlu, kalau tidak ada lampu lalu lintas, lalu lintas akan kacau. Semua saling egois mau jalan duluan (Wawancara Akmal Rizky, n.d.).

Hasil wawancara menyatakan sebagian siswa mengerti dan memahami akan hukum lalu lintas yang berlaku, namun pada beberapa hasil wawancara juga didapati banyak hal-hal kaitan pelanggaran lalu lintas yang kerapkali dilakukan oleh siswa, seperti pada hasil wawancara dengan salah seorang siswa yang mengatakan melakukan pelanggaran berboncengan lebih dari 2-3 dengan alasan mengirit BBM.

Karena kalau di anter satu persatu memakan bensin dan waktu yang lebih sehingga harus berbonceng lebih dari dua akibat kekurangan motor (Wawancara Akmal Rizky, n.d.)

Ada juga siswa yang memberikan mengatakan menghemat waktu dan kasihan pada temanya, yang kemudian jadi alasan untuk melakukan pelanggaran lalu lintas.

Karena kasian kalau ada teman yang numpang jika tidak dibolehkan satunya sendirian berjalan kaki.dan Kebetulan pada saat itu ada suatu kepentingan ditempat yang sama, oleh karena itu berboncengan lebih dari dua menghemat waktu juga (Wawancara Ayu Yuningsih, n.d.).

Berboncengan lebih dari 2 selain menyalahi aturan juga sangat berbahaya, dengan berboncengan lebih dari 2 akan mengurangi konsentrasi untuk berkendara dengan baik dikarenakan posisi standar kenyamanan berkendara tidak terpenuhi, dan pengendara akan cenderung uring-uringan dalam berkendara.

Selain pelanggaran berboncengan lebih dari 2 beberapa siswa juga mengaku melakukan beberapa pelanggaran, seperti lampu merah dan rambu-rambu lalu lintas, yang sebenarnya dia sangat sadar dampak negative dari pelanggaranya tersebut.

Pelanggaran lalu lintas yang pernah saya lakukan yaitu menerobos lampu lalu lintas, tidak menghidupkan lampu disiang hari, berboncengan lebih dari dua, dan pernah seharusnya tidak boleh memutar balik saya memutar balik (Wawancara Muhammad Soleh, n.d.).

Tak jarang juga mereka menjadikan peluang kosong nya jalanan sebagai alasan 
untuk melanggar lalu lintas,

Karena terburu-buru kadang kalau menunggu atau tidak memutar balik menjadi memakan waktu yang lama, dan melihat kondisi dirasa aman yang juga ikut mendukung (Wawancara Bunga Ayu Lestari, n.d.).

Salah satu bukti dari warga negara yang baik adalah dengan taat akan aturan yang berlaku di negaranya termasuk pada aturan laulintas yang berlaku, karena pada dasarnya aturan dibuat untuk menertibkan dan menata system yang tidak beratuan, dalam hal apaun manusia akan lebih memilih sesuatu yang teratur dan rapih, tentu akan sangat indah dan nyaman jika aturan lalu lintas dapat di taati oleh semua warganya, maka akan sangat jarang terjadi kecelakaan lalu lintas, jalanan akan sangat tertib dan teratur.

Pengendara yang baik itu mematuhi tata tertib lalu lintas, pengendara itu harus sabar, misalnya ketika melewati lampu lalu lintas yang waktunya cukup lama tetapi kita harus sabar karena lampu lintas menghindarkan kita dari kecelakaan lalu lintas. ${ }^{37}$

Dari hasil wawancara tentang pelanggaran lalu lintas seluruh siswa yang saya wawancarai menyatakan setidaknya pernah melakukan satu jenis pelanggaran yang sering dilakukan dengan pembenaran dan alasan beragam. Pemahaman siswa tentang hukum lalu lintas tidak berbanding lurus dengan penerapan dalam keseharian aktivitas berlalu lintasnya, sehingga tentu dapat dikatakan bahwa kesadaran siswa akan taat hukum lalu lintas sangat rendah.

\section{Peranan Guru PAI dalam Membentuk Kesadaran Hukum Berlalu Lintas, Faktor Pendukung dan Penghambat Guru PAI}

Guru Pendidikan Agama Islam memegang peranan penting dalam meningkatkan kesadaran hukum berlalu lintas pada siswa kelas XII SMK TEXMACO Purwasari. Peranan yang dilakukan oleh guru Pendidikan Agama Islam dalam meningkatkan kesadaran hukum berlalu lintas pada siswa kelas XII SMK TEXMACO Purwasari dilakukan dengan beberapa kegiatan yang dilakukan di dalam maupun di luar kelas.

Menurut Arlan Suherlan, salah satu guru Pendidikan Agama Islam di SMK Texmaco Purwasari menjelaskan, semua parlemen sekolah dari guru maupun staff semua punya peran dan ikut andil untuk memberikan contoh yang baik terhadap siswa, bukan hanya guru PAI saja karena sejatinya guru itu digugu dan ditiru. 
Cara guru PAI untuk mengetahui sejauh mana perkembangan siswa-siswanya dengan cara melihat dalam kegiatan kesehariannya di kelas atau di luar kelas, akankah ternanam nilai-nilai yang sudah diberikan atau belum dan masih saja belum ada perubahan. Menurut Ridwan Wijaya Kusuma, ketika di wawancarai tentang bagaimana peran guru PAI dalam menumbuhkan kesadaran siswa dalam berlalu lintas.

Terdapat beberapa peranan yang diperlukan dari guru sebagai pendidik. Peranan tersebut antara lain adalah guru berperan sebagai korektor, inspirator, informator, organisator, motivator, inisiator, fasilitator, pembimbing, demonstrator, pengelola kelas, mediator, supervisor, dan evaluator ("Wawancara Ridwan Wijaya Kusuma," n.d.).

Dalam meningkatkan kesadaran hukum berlalu lintas kepada siswa, tim guru PAI juga memiliki hal-hal yang merupakan suatu faktor pendukung dan penghambat dalam menjalankan perannya di sekolah. Adapun faktor pendukung dan penghambat tersebut.

Adapun faktor pendukungnya antara lain tersedianya lahan parkir kendaraan siswa di dalam sekolah, agar guru bisa mengecek kelengkapan dan kesadaran siswa ketika membawa kendaraan ke sekolah. Selanjutnya dekat dengan tempat aparat keamanan yaitu Polsek purwasari dan kecamatan Purwasari, agar pengawasan siswa dalam berkendara lebih intens dan lebih aman. Selain faktor pendukung ada juga faktor penghambatnya, ketika wawancara dengan Ridwan Wijaya Kusumah, yaitu :

1. Minimnya Sosialisasi guru tentang lalu lintas,

2. Kurangnya kegiatan keagamaan dalam membentuk kesadaran siswa,

3. Kurang tegasnya aturan dari pihak sekolah terhadap siswa yang dibawah umur 17 tahun dan atau belum memiliki SIM.

4. Kuranganya pengetahuan orang tua dalam memahami peraturan lalu lintas,

Sikap acuh tak acuh siswa kelas XII SMK Texmaco Purwasari terhadap peraturan lalu lintas, dan Pengaruh lingkungan di luar sekolah terhadap siswa kelas XII SMK Texmaco Purwasari (“Wawancara Ridwan Wijaya Kusuma,” n.d.). 


\section{E. Penutup}

Berdasarkan paparan data serta pembahasan yang telah penulis ungkapkan, maka kesimpulan penelitian ini adalah sebagai berikut: Pertama, Mengenai Kesadaran Hukum berlau lintas siswa di kelas XII SMK Texmaco Purwasari ini hampir seluruhnya mengetahui terhadap hukum berlalu lintas. Mereka juga mengetahui hal-hal yang menjadi kewajiban seorang pengendara dan hal-hal yang tidak boleh dilakukan seperti halnya, Mengendarai sepeda motor itu harus memiliki SIM C, larangan menggunakan HP saat berkendara, dll. Pemahaman siswa tentang undang-undang no.22 tahun 2009 dapat kita lihat bahwa hanya sebagian saja yang mengetahui dan mengerti tentang undang-undang no.22 tahun 2009 tentang lalu lintas, karena kurangnya sumber informasi yang mereka dapatkan.

Kedua, Adapun peran Guru PAI dalam meningkatkan kesadaran hukum berlalu lintas siswa antara lain : a) pertama sebagai Informator yaitu guru Pendidikan Agama Islam memberikan informasi kepada siswa kelas XII SMK Texmaco Purwasari berupa pengetahuan dalam berlalu lintas, b) Peranan yang kedua yaitu sebagai organisator, artinya guru memiliki kegiatan pegelolaan dalam kegiatan akademik sehingga dapat mencapai efektivitas dan efisiensi dalam belajar pada diri anak, c) Peranan yang ketiga yaitu sebagai motivator. Sebagai motivator artinya guru Pendidikan Agama Islam memberikan motivasi tentang pentingnya mematuhi peraturan lalu lintas kepada siswa, d) Peranan yang Keempat yaitu sebagai fasilitator, dimana Kegiatan yang dilakukan oleh bapak Ridwan Wijaya Kusuma dalam berperan sebagai fasilitator yaitu dengan melakukan kegiatan pembelajaran menggunakan video pembelajaran yang menarik bagi siswa, e) Peranan yang kelima yaitu sebagai pembimbing, dimana dalam menjalankan perananannya sebagai pembimbing guru Pendidikan Agama Islam memberikan bimbingan melalui kegiatan pembelajarannya di kelas, dan terakhir f) Peranan yang terakhir yaitu sebagai pengelola kelas, menjadikan kelas yang nyaman bagi para siswa dengan di siapkan dulu sebelum pembelajaran. 


\section{DAFTAR PUSTAKA}

Asiah, N. (2009). Generasi Taat Hukum. Fikra Publika.

Gunawan, H. (2011). Pengembangan Kompetensi Kepribadian Guru. Alfabeta.

Harahap, E. S. (2018). Peranan orang tua Dalam Meningkatkan Partisipasi Anak Pendidikan 12 Tahun Di Desa Berangas Kecamatan Pulau Laut Timur Kabupaten Kotabaru. Muttaqien Publsihing.

Hasibuan, J. P. (2007). Kesadaran Hukum Masyarakat Terhadap Hukum Waris. UNNES Press.

Kuncorowati, P. W. (2009). Menurunnya Tingkat Kesadaran Hukum Manyarakat di Indonesia. Jurnal Civics, 6(2), 2.

Laksamana. (2010). Kesadaran Berlalu Lintas Untuk Mencegah Angka Kecelakaan. Jurnal Ilmiah Abdi Ilmu, 3(2), 2.

Manpan Drajat, M. R. E. (2015). Etika Ptrofesi Guru. Alfabeta.

Muhamad Ridwan Effendi, Rudi M. Barnansyah, S. N. (2019). Model Pendidikan Inklusif Pondok Pesantren. Laboratorium PAI FIS UNJ. https://seminars.unj.ac.id/icic/

Samrin. (2015). Pendidikan Agama Islam Dalam Sistem Pendidikan Nasional Di Indonesia. Jurnal Al-Ta'dib, 8(1), 104-105.

Wawancara Akmal Rizky. (n.d.).

Wawancara Alin Noor Kholis. (n.d.).

Wawancara Ayu Yuningsih. (n.d.).

Wawancara Bunga Ayu Lestari. (n.d.).

Wawancara Muhammad Soleh. (n.d.).

Wawancara Ridwan Wijaya Kusuma. (n.d.). In Oktober 2019.

Wawancara Taopik Paridi. (n.d.).

Yuliana, I. (2019), penggunaan kendaraan bermotor oleh anak dibawah umur. Alfabeta. 